\title{
Correction: Challenges in Engaging Birdwatchers in Bird Monitoring in a Forest Patch: Lessons for Future Citizen Science Projects in Agricultural Landscapes
}

\author{
Eduardo Roberto Alexandrino*, Ana Beatriz Navarro*, Valdir Felipe Paulete', \\ Maristela Camolesi*,, Vosmarline Graziela Rocha Lima†, Austin Green§, Tiago de Contoll, \\ Katia Maria Paschoaletto Micchi de Barros Ferraz*, Çağan Hakkı Şekercioğlus,n and \\ Hilton Thadeu Zarate do Coutoll
}

This article details a correction to the article: Alexandrino, E.R., Navarro, A.B., Paulete, V.F., Camolesi, M., Lima, V.G.R., Green, A., de Conto, T., Ferraz, M.P.M. de B., Şekercioğlu, C..H. and do Couto, H.T.Z., 2019. Challenges in Engaging Birdwatchers in Bird Monitoring in a Forest Patch: Lessons for Future Citizen Science Projects in Agricultural Landscapes. Citizen Science: Theory and Practice, 4(1), p.4. DOI: http:// doi.org/10.5334/cstp.198

Keywords: avian ecology; participatory science; birdwatching; bird banding; bird resighting; forest restoration; ornithology; serious leisure; tropical biology; ecotourism

\section{Correction}

After publication of Alexandrino et al. (2019) it was brought to light that a co-author's name was presented incorrectly. The authors would like to correct the appearance of the name Maria Paschoaletto Micchi de Barros Ferraz to Katia Maria Paschoaletto Micchi de Barros Ferraz in the author list.

\section{Competing Interests}

The authors have no competing interests to declare.

\section{Reference}

Alexandrino, ER, Navarro, AB, Paulete, VF, Camolesi, M, Lima, VGR, Green, A, de Conto, T, Ferraz, MPMdeB, Şekercioğlu, ÇH and do Couto, HTZ. 2019. Challenges in Engaging Birdwatchers in Bird Monitoring in a Forest Patch: Lessons for Future Citizen Science Projects in Agricultural Landscapes. Citizen Science: Theory and Practice, 4(1): 4. DOI: https://doi. org/10.5334/cstp.198

\footnotetext{
* Universidade de São Paulo - USP, Escola Superior de Agricultura "Luiz de Queiroz" - ESALQ, Laboratório de Ecologia, Manejo e Conservação de Fauna Silvestre - LEMaC, Av. Pádua Dias, Piracicaba, SP, BR

- Universidade Metodista de Piracicaba - UNIMEP. Rodovia do açúcar, Km 156 - Taquaral, Piracicaba, SP, BR

₹ Universidade Federal de São Carlos - UFSCar, campus Sorocaba. Rod. João Leme dos Santos, Km, Sorocaba, SP, BR

$\S$ University of Utah, Department of Biology, Biodiversity and
}

Conservation Ecology Lab, 257 South 1400 East, Salt Lake City, UT, US

" Universidade de São Paulo - USP, Escola Superior de Agricultura "Luiz de Queiroz" - ESALQ, Laboratório de Métodos Quantitativos - LMQ, Av. Pádua Dias, Piracicaba, SP, BR

" Koç University, College of Sciences, Rumelifeneri, Sariyer 34450, Istanbul, TR

Corresponding author: Eduardo Roberto Alexandrino (eduardoalexandrino@hotmail.com) 
How to cite this article: Alexandrino, ER, Navarro, AB, Paulete, VF, Camolesi, M, Lima, VGR, Green, A, de Conto, T, Ferraz, KMPMdeB, Şekercioğlu, CH and do Couto, HTZ. 2019. Correction: Challenges in Engaging Birdwatchers in Bird Monitoring in a Forest Patch: Lessons for Future Citizen Science Projects in Agricultural Landscapes. Citizen Science: Theory and Practice, 4(1): 17, pp. 1-2. DOI: https://doi.org/10.5334/cstp.247

\section{Submitted: 18 April 2019 \\ Accepted: 18 April 2019 \\ Published: 10 May 2019}

Copyright: (c) 2019 The Author(s). This is an open-access article distributed under the terms of the Creative Commons Attribution 4.0 International License (CC-BY 4.0), which permits unrestricted use, distribution, and reproduction in any medium, provided the original author and source are credited. See https://creativecommons.org/licenses/by/4.0/.

] $\mathrm{u}$ [ Citizen Science: Theory and Practice is a peer-reviewed open access journal published by Ubiquity Press. 